\title{
Investigation of the Anti-inflammatory and Hypoglycaemic Effects of Macaranga hurifolia Beille (Eurphorbiaceae) Extract on Wistar albino Rats
}

\author{
Peter Segun ${ }^{1 *}$, Morenike Gbadeb0 ${ }^{1}$, Modupe Adebowale ${ }^{1}$, Katherine Olufolabo ${ }^{1}$, \\ Adediwura Fred-Jaiyesimi ${ }^{1}$ \\ 1Department of Pharmacognosy, Faculty of Pharmacy, Olabisi Onabanjo University, Sagamu 8 Campus, Nigeria.
}

\begin{abstract}
Macaranga hurifolia Beille (Euphorbiaceae) is used in Nigerian ethnobotany for treating several diseases. This work was designed to determine the phytochemical composition, as well as, investigate the anti-inflammatory and hypoglycaemic activities of Macaranga hurifolia extract (MHE). MHE was evaluated for its anti-inflammatory and antidiabetic potentials using the egg albumin inflammatory model and alloxan-induced diabetic rat model, respectively. MHE produced both dose-dependent and time-dependent inhibition of oedema development with its maximum effect (69.6\%) produced at the dose of $300 \mathrm{mg} / \mathrm{kg}$. The acute in vivo antidiabetic study revealed that MHE produced significant hypoglycaemic effects at doses of $200 \mathrm{mg} / \mathrm{kg}$ (54\% reduction) and $400 \mathrm{mg} / \mathrm{kg}$ ( $59 \%$ reduction), comparable to glibenclamide $(5 \mathrm{mg} / \mathrm{kg}$ ) which caused a $42 \%$ decrease, while all the treatment groups produced at least $25 \%$ reduction in blood glucose level for the chronic study. This study established, for the first time, the anti-inflammatory and antidiabetic potentials of Macaranga hurifolia.
\end{abstract}

Keywords: Alloxan, diabetes mellitus, egg albumin, inflammation, Macaranga hurifolia

\section{INTRODUCTION}

Diabetes mellitus (DM) continues to impose a major threat on global human

*Corresponding Author: Peter Segun, e-mail: segun.peter@oouagoiwoye.edu.ng

Peter Segun ORCID Number: 0000-0002-2177-4609

Morenike Gbadebo ORCID Number: 0000-0002-5664-8397

Modupe Adebowale ORCID Number: 0000-0002-0944-0702

Katherine Olufolabo ORCID Number: 0000-0003-3054-9339

Adediwura Fred-Jaiyesimi ORCID Number: 0000-0002-5906-9155

(Received 17 April 2019, accepted 08 August 2019) 
health affecting around $25 \%$ of the world population and the number of people suffering from this ailment is projected to reach 439 million by $2030^{1,2}$. DM is a major metabolic disorder characterized by improper management of carbohydrate and lipid metabolism by insulin, often leading to high blood glucose levels. This ailment may either result from the autoimmune destruction of the pancreatic islet beta cells leading to inadequate endogenous production of insulin; a condition known as type $1 \mathrm{DM}$ or the impaired insulin secretion and/ or insulin resistance; a condition commonly referred to as type $2 \mathrm{DM}^{3}$. Inflammation, the response of viable tissues to injury, involves several mechanisms including enzyme activation, release of mediators, extravasations of fluid, and tissue breakdown and repair. Non-steroidal anti-inflammatory drugs (NSAIDs) have been the main stay in the treatment of inflammation, although adverse effects on the gastric mucosa and kidney have limited their therapeutic success.

Hyperglycaemia, a major feature of DM, is often linked with increase oxidative stress and inflammatory responses. In particular, excessive flow of glucose through the aldose reductase metabolic pathway leads to the oxidation of NA$\mathrm{DPH}$ to $\mathrm{NADP}^{+}$and the reduction of $\mathrm{NAD}^{+}$to $\mathrm{NADH}^{4,5}$. This change in redox potential leads to cell hypoxia, acceleration of glycolysis, increase production of superoxide and the eventual activation of the protein kinase $\mathrm{C}(\mathrm{PKC})^{6}$. The activation of PKC reduces the availability of nitric oxide, causes endothelial dysfunction leading to the release of several endothelial inflammatory biomarkers including Von Willebrand factor (VWF), interleukin-6 (IL-6), tumor necrosis factor-alpha (TNF- $\alpha$ ), intercellular adhesion molecule-1 (ICAM-1), thromboxane A2 (TA2) ${ }^{7,8}$. Several studies have shown that oxidative stress and inflammatory responses play key roles in the development of microvascular and macrovascular complications in diabetic patients as many of the important pro-inflammatory mediators have been reported to be present in high amount in diabetic patients ${ }^{9}$.

Despite the great progress made in orthodox medicine towards the management of DM as exemplified in the discovery and development of current antidiabetic agents including sulfonylureas, biguanides, thiazolidinediones and a-glucosidase inhibitors ${ }^{10}$, complications such as weight gain, hypoglycaemia, dropsy and drug-resistance that often arise from the use of these agents have necessitated the search for alternative treatment for $\mathrm{DM}^{11}$. Consequently, there is a great need for the discovery of novel molecules, especially from natural sources such as medicinal plants, that can tackle the problem posed by DM.

Macaranga hurifolia Beille (Euphorbiaceae) is a short tree up to $12 \mathrm{~m}$ high that is found in forest and savannah regions of Cameroon, Nigeria and Sierra 
Leone. It is commonly referred to as 'owolewa' by the Yoruba speaking people of southwestern Nigeria ${ }^{12}$. It is used traditionally for its medicinal values and as its branches are widely used as fire woods. In traditional folklore medicine, $M$. hurifolia is used to treat cough and diabetes, to relieve oedema in pregnant women and as a purgative. Although several studies have investigated the phytochemical constituents and the bioactivities of numerous Macaranga species including $M$. barteri and $M$. schweinfurthi $\ddot{i}^{13-17}$, the literature is void of report on the phytochemical constituents, anti-inflammatory and antidiabetic potentials of $M$. hurifolia. Therefore, the aim of this study is to determine the phytochemical composition, as well as, investigate the hypoglycaemic and anti-inflammatory activities of $M$. hurifolia extract (MHE).

\section{METHODOLOGY}

\section{Materials}

The fresh leaves of $M$. hurifolia were collected in March 2018 in Epe (6 $6^{\circ} 35^{\prime}$ 2.83 " $\mathrm{N}$ and $3^{\circ} 59^{\prime}$ 0.10" E, altitude $42 \mathrm{~m}$ ), Lagos State, Nigeria. The plant identification and authentication were carried out by Mr A. S. Odewo at the Forest Herbarium Unit, Forestry Research Institute of Nigeria (FRIN), Ibadan, Nigeria where an herbarium specimen with voucher number FHI 111956 has been deposited. The plant's name was checked at http://www.theplantlist.org (assessed on 27th, April 2018). All chemicals and reagent used were of analytical grade and purchased from Sigma Co. UK.

\section{Animals}

Male Wistar albino rats, 220 -250 g, obtained from Babcock University, Ilishan, Nigeria, were used for this study. The animals were bred and housed in the animal house, Faculty of Pharmacy, Olabisi Onabanjo University. The animal house was well ventilated with room temperature between 25 and 29 ${ }^{\circ} \mathrm{C}$ and had a $12 \mathrm{~h}$ light-dark cycle and were housed in groups. The rats were fed with rodent commercial diet and water ad libitum and allowed to acclimatise to laboratory environment for one week prior to the experiment. The animals were maintained in accordance with the guidelines of the International Guidelines for Care and Use of Laboratory Animals ${ }^{18}$ and approval from the Animal Ethical Committee was obtained.

\section{Preparation of crude extract}

The air-dried, powdered leaves of $M$. hurifolia were macerated with $80 \%$ methanol at room temperature $\left(25-29{ }^{\circ} \mathrm{C}\right)$ and filtered. The obtained filterate was concentrated in vacuo at $35{ }^{\circ} \mathrm{C}$ using rotary evaporator. The extract (yield: $8.1 \%$ ) was stored in a clean amber bottle and kept in a refrigerator at $4{ }^{\circ} \mathrm{C}$ prior to use. 


\section{Phytochemical screening}

The presence of various secondary metabolites in the plant was investigated using standard procedures ${ }^{19}$. The chemical groups of compounds tested were alkaloids, anthraquinones, cardiac glycosides, flavonoids, reducing sugars, saponins, steroids and tannins.

\section{Anti-inflammatory activity}

For the determination of the anti-inflammatory potential of MHE, the egg albumin inflammatory model described previously in the literature was adopted with slight modifications ${ }^{20}$. Briefly, thirty male Wistar rats were divided into six groups each group containing five rats. The rats were starved for $12 \mathrm{~h}$ prior to the experiment and also deprived of water to reduce possible fluctuations in oedematous response. To induce inflammation, fresh egg albumin (0.1 mL) was injected into the subplantar surface of the right hind paw of each animal and allowed to stay for $1 \mathrm{~h}$ prior to treatment with extract/drug. The extract was administered to group 1, group 2, group 3 and group 4 at doses of $300 \mathrm{mg} / \mathrm{kg}$, $150 \mathrm{mg} / \mathrm{kg}, 75 \mathrm{mg} / \mathrm{kg}$ and $37.5 \mathrm{mg} / \mathrm{kg}$, respectively. Group 5 which served as the positive control group received diclofenac $(50 \mathrm{mg} / \mathrm{kg}$ ), while the negative control group (group 6) received normal saline. All treatments were administered using an oral canula. The paw circumference was estimated using cotton thread method ${ }^{21}$ with measurements made prior to the start of the experiment and subsequently every $30 \mathrm{~min}$ after treatment with extract/drug for a total of $120 \mathrm{~min}$.

\section{Induction of Type 2 DM in rats and drug administration}

Investigation of the effect of $M$. hurifolia extract (MHE) on type $2 \mathrm{DM}$ rats was carried out following a procedure described earlier in the literature ${ }^{22}$. The rats were fasted overnight before the commencement of the experiment. Thereafter, intraperitoneal administration of alloxan monohydrate solution (dissolved in normal saline) at a dose of $140 \mathrm{mg} / \mathrm{kg}$ body weight was given to the rats. Forty-eight hours after alloxan injection, the fasting blood glucose level (FBG) was measured and rats with FBG level above $250 \mathrm{mg} / \mathrm{dL}$ were considered diabetic and used for further investigations. For the examination of the anti-hyperglycaemic potential of MHE, the rats were divided into six groups of five rats each. Group 1, which served as the normal control group, were normoglycaemic rats that received normal saline at a dose of $1 \mathrm{~mL} / \mathrm{kg}$. Group 2, the diabetic control group, comprised of diabetic rats that received no treatment. Group 3 which served as the standard treatment group were rats that received a treatment of glibenclamide at a dose of $5 \mathrm{mg} / \mathrm{kg}$. Groups 4, 5 and 6 were administered MHE at doses of 100, 200 and $400 \mathrm{mg} / \mathrm{kg}$, respectively. All the groups were treated 
appropriately for seven days. Blood samples were obtained from the tail veins of the experimental animals using a sterile lancet and the blood glucose levels measured at oh, $1 \mathrm{~h}, 3 \mathrm{~h}, 6 \mathrm{~h}$ and $24 \mathrm{~h}$ after drug administration on the first day, using a glucometer (One-Touch $囚$ ). Treatment with MHE and measurement of the blood glucose level was subsequently conducted daily for seven days.

\section{Statistical analysis}

Results obtained were expressed as mean \pm standard error of mean $(n=5)$ and the data were analysed using the student's t-test and values of $\mathrm{p}<0.05$ were considered statistically significant.

\section{RESULTS AND DISCUSSION}

$\mathrm{DM}$ is a major predisposing factor to the formation of myocardial infarction, cerebrovascular accident and peripheral vascular diseases and recent studies have reported that diabetic sufferers are almost five times more probable of developing heart diseases and stroke that non-diabetic individuals ${ }^{6,23}$. In the recent times, emphasis has been laid on the discovery of newer drugs for the treatment of DM and inflammation from traditional medicine, especially from medicinal plants, due to the untoward effects of the currently available synthetic medications. In this study, the anti-inflammatory and hypoglycaemic effects of Macaranga hurifolia leaves extract (MHE) was investigated.

The analysis of the phytochemical constituents of MHE revealed that it contains several secondary metabolites including alkaloids, flavonoids, saponins and tannins (Table 1). These metabolites 7 which have been reported in other members of the Macaranga genus ${ }^{16,17,24}$, may be responsible for its observed bioactivity. In addition, saponins and tannins have been reported to possess anti-inflammatory activity in several in vivo models ${ }^{25}$.

Table 1. Phytochemical constituents of $M$. hurifolia methanol extract (MHE)

\begin{tabular}{cc}
\hline Phytochemicals & Results \\
\hline Alkaloids & +++ \\
Anthraquinones & - \\
Cardiac glycosides & - \\
Flavonoids & ++ \\
Saponins & ++ \\
Sterols & - \\
Tannins & + \\
\hline
\end{tabular}

- = absent; + = present; ++ = abundant 
The subplantar administration of egg albumin into the right hind paw of male Wistar rats elicited oedema which peaked at $60 \mathrm{~min}$ post administration of the agent. MHE caused both dose-dependent and time-dependent inhibition of oedema development. The maximum inhibition of oedema development (69.6\%) was produced at the dose of $300 \mathrm{mg} / \mathrm{kg}$ at the $120 \mathrm{~min}$ interval, an effect comparable but not significantly different from that elicited by $50 \mathrm{mg} /$ $\mathrm{kg}$ diclofenac (73.1\%) at the same time interval (Table 2). Previous research have shown that induction of oedema elicited by egg albumin is mediated by the release of vasoactive substances, especially histamine and serotonin ${ }^{26}$. The significant inhibitory effect on rat paw development exhibited by MHE suggest that the extract may likely inhibit the release and/or actions of histamine and serotonin.

The hypoglycaemic effect of MHE and glibenclamide (positive control) are shown in Tables 2 and 3. From the acute in vivo antidiabetic study designed to evaluate the effect of MHE over a short period of time, it was observed that DHE at a dose of $200 \mathrm{mg} / \mathrm{kg}$ and $400 \mathrm{mg} / \mathrm{kg}$ significantly reduced the blood glucose level of diabetic rats by $54 \%$ and $59 \%$, respectively, over the $24 \mathrm{~h}$ period, comparable to glibenclamide $(5 \mathrm{mg} / \mathrm{kg}$ ) which caused a $42 \%$ decrease over the same treatment period (Table 3). Several studies have reported that a reduction in the blood glucose level by $25 \%$ is to be considered as a significant hypoglycaemic effect ${ }^{27-29}$.

Table 2. Anti-inflammatory effects of MHE on egg albumin-induced rat paw oedema

\begin{tabular}{ccccccc}
\hline $\begin{array}{c}\text { Treatment } \\
\text { groups }\end{array}$ & $\begin{array}{c}\text { Dose } \\
(\mathbf{m g} / \mathbf{k g})\end{array}$ & \multicolumn{4}{c}{ Paw thickness $(\mathbf{m m})^{\mathrm{a}}$} & \multirow{2}{*}{$\begin{array}{c}\% \\
\text { inhibition }\end{array}$} \\
\cline { 3 - 6 } & $\mathbf{3 0} \mathbf{~ m i n}$ & $\mathbf{6 0} \mathbf{~ m i n}$ & $\mathbf{9 0 ~} \mathbf{m i n}$ & $\mathbf{1 2 0} \mathbf{~ m i n}$ & \\
\hline $\begin{array}{c}\text { Normal } \\
\text { saline }\end{array}$ & $10(\mathrm{~mL} / \mathrm{kg})$ & $3.26 \pm 0.38$ & $3.23 \pm 0.12$ & $3.16 \pm 0.15$ & $2.86 \pm 0.26$ & - \\
MHE & 37.5 & $3.66 \pm 0.23$ & $3.33 \pm 0.52$ & $3.13 \pm 0.51$ & $3.00 \pm 0.43$ & 12.5 \\
MHE & 75 & $3.56 \pm 0.10$ & $3.03 \pm 0.32$ & $2.56 \pm 0.38$ & $2.90 \pm 0.23$ & 30 \\
MHE & 150 & $3.8 \pm 0.26$ & $3.40 \pm 0.20$ & $2.90 \pm 0.17$ & $2.72 \pm 0.40$ & 56.3 \\
MHE & 300 & $3.56 \pm 0.10$ & $2.60 \pm 0.26$ & $2.66 \pm 0.17$ & $2.70 \pm 0.10$ & 69.6 \\
Diclofenac & 50 & $3.36 \pm 0.66$ & $3.33 \pm 0.58$ & $3.13 \pm 0.66$ & $2.90 \pm 0.36$ & 73.1 \\
\hline
\end{tabular}

aValues are expressed as mean \pm standard error of mean of five rats per group.

* denotes percentage inhibition of oedema development with respect to the control. 
Table 3. Acute effect of M. hurifolia crude extract (MHE) on fasting glucose level in alloxaninduced diabetic rats

\begin{tabular}{cccccc}
\hline Treatment & \multicolumn{5}{c}{ Fasting blood glucose (mg/dL) } \\
\cline { 2 - 6 } groups & $\mathbf{0 ~ h}$ & $\mathbf{1 ~ h}$ & $\mathbf{3 ~ h}$ & $\mathbf{6 ~ h}$ & $\mathbf{2 4 ~ h}$ \\
\cline { 2 - 6 } Group 1 & $110.0 \pm 11.2$ & $105.0 \pm 11.2$ & $96.0 \pm 4.0$ & $98.5 \pm 4.4$ & $68.3 \pm 6.8$ \\
Group 2 & $332.3 \pm 10.8$ & $369.8 \pm 7.8$ & $362.5 \pm 9.9$ & $354.5 \pm 5.1$ & $436.0 \pm 16.1$ \\
Group 3 & $415.5 \pm 16.1$ & $373.8 \pm 22.4$ & $359.0 \pm 15.7$ & $304.0 \pm 17.3$ & $241.5 \pm 15.5^{b}$ \\
& & & & & $(41.9 \%)^{*}$ \\
Group 4 & $260.7 \pm 16.0$ & $371.0 \pm 15.8$ & $160.3 \pm 16.5^{b}$ & $227.8 \pm 16.9^{b}$ & $218.5 \pm 7.8^{b}$ \\
& & & & & $(15.96 \%)^{*}$ \\
Group 5 & $444.5 \pm 16.4$ & $415.5 \pm 16.5$ & $370.5 \pm 13.7$ & $272.5 \pm 7.4^{b}$ & $205.5 \pm 11.7^{b}$ \\
& & & & & $(53.76 \%)^{*}$ \\
Group 6 & $347.3 \pm 15.5$ & $279.0 \pm 16.9^{b}$ & $195.6 \pm 12.5^{b}$ & $166.0 \pm 9.3^{b}$ & $143.6 \pm 8.4^{b}$ \\
& & & & & $(58.61 \%)^{*}$ \\
\hline
\end{tabular}

aValues are expressed as mean \pm standard error of mean of five rats per group. bStatistically different from the diabetic control $(P<0.05)$. Group 1 were normoglycaemic rats; group 2 were diabetic rats that received no treatment; group 3 were diabetic rats that received a treatment of glibenclamide at a dose of $5 \mathrm{mg} / \mathrm{kg}$; groups 4,5 and 6 were diabetic rats that were given TBE at doses of 100, 200 and $400 \mathrm{mg} / \mathrm{kg}$, respectively. ${ }^{*}$ denotes percentage reduction of the blood glucose level with respect to the time $0 \mathrm{~h}$.

For the chronic antidiabetic model (seven days treatment period), all the treatment groups had reduction in the blood glucose levels more than $25 \%$, with the diabetic rats administered with DHE at doses of $200 \mathrm{mg} / \mathrm{kg}$ been the most significant (73\%), compared to glibenclamide that resulted in 69\% decrease in blood glucose level (Table 4). 
Table 4. Chronic effect of $M$. hurifolia crude extract (MHE) on fasting glucose level in alloxaninduced diabetic rats

\begin{tabular}{cccc}
\hline Treatment groups & \multicolumn{3}{c}{ Fasting blood glucose (mg/dL) } \\
\cline { 2 - 4 } Group 1 & Day 1 & Day 2 & Day 3 \\
\cline { 2 - 4 } Group 2 & $68.3 \pm 6.8$ & $89.8 \pm 11.1$ & $90.3 \pm 9.12$ \\
Group 3 & $436.0 \pm 16.1$ & $366.5 \pm 20.5$ & $378.3 \pm 12.6$ \\
Group 4 & $241.5 \pm 15.5^{\mathrm{b}}$ & $315.8 \pm 13.5$ & $225.5 \pm 13.6^{\mathrm{b}}$ \\
Group 5 & $218.5 \pm 7.8^{\mathrm{b}}$ & $285.5 \pm 10.9^{\mathrm{b}}$ & $308.3 \pm 17.5$ \\
Group 6 & $205.5 \pm 11.7^{\mathrm{b}}$ & $326.6 \pm 16.3$ & $285.3 \pm 18.5$ \\
\hline & $143.6 \pm 8.4^{\mathrm{b}}$ & $188.8 \pm 11.3^{\mathrm{b}}$ & $181.8 \pm 10.9^{\mathrm{b}}$ \\
\hline Day 4 & & & \\
\hline $85.5 \pm 13.1$ & $86.0 \pm 9.34$ & $87.7 \pm 7.99$ & $85.8 \pm 6.89$ \\
$368.0 \pm 14.9$ & $364.0 \pm 14.7$ & $346.8 \pm 17.5$ & $344.5 \pm 19.39$ \\
$234.8 \pm 11.6^{\mathrm{b}}$ & $206.8 \pm 10.9^{\mathrm{b}}$ & $163.0 \pm 17.3^{\mathrm{b}}$ & $130.5 \pm 19.5^{\mathrm{b}}(68.7 \%)^{\star}$ \\
$217.5 \pm 12.4^{\mathrm{b}}$ & $243.0 \pm 22.8$ & $236.0 \pm 15.3$ & $182 \pm 11.7^{\mathrm{b}}\left(30.2^{*}\right)^{*}$ \\
$268.0 \pm 17.8$ & $198.3 \pm 15.2^{\mathrm{b}}$ & $147.3 \pm 12.6^{\mathrm{b}}$ & $118.6 \pm 17.0^{\mathrm{b}}\left(73.3^{\mathrm{b}}\right)^{\star}$ \\
$247.5 \pm 1.8$ & $202.8 \pm 14.9^{\mathrm{b}}$ & $161.8 \pm 11.2$ & $107.7 \pm 18.2^{\mathrm{b}}(69.0 \%)^{\star}$ \\
\hline
\end{tabular}

aValues are expressed as mean \pm standard error of mean of five rats per group. bStatistically different from the diabetic control $(P<0.05)$. Group 1 were normoglycaemic rats; group 2 were diabetic rats that received no treatment; group 3 were diabetic rats that received a treatment of glibenclamide at a dose of $5 \mathrm{mg} / \mathrm{kg}$; groups 4,5 and 6 were diabetic rats that were given TBE at doses of 100, 200 and $400 \mathrm{mg} / \mathrm{kg}$, respectively. * denotes percentage reduction of the blood glucose level with respect to the time $0 \mathrm{~h}$.

To the best of our knowledge, this is the first report on the anti-inflammatory and antidiabetic activities of the methanol extract of the leaves of Macaranga hurifolia. Other members of this genus have been reported to display antidiabetic effects. For instance, the chloroform fraction of the leaves of $M$. barteri lowered the blood glucose level in alloxan induced diabetic rats, with lupeol acetate responsible for the antidiabetic property of the leaves ${ }^{30}$. In addition, macatannins A and B isolated from the leaves of $M$. tanarius displayed remarkable $\alpha$-glucosidase inhibitory activity ${ }^{31}$.

This study has demonstrated the anti-inflammatory and antidiabetic activities of the methanol extract of Macaranga hurifolia. Further work is ongoing to isolate, purify and structurally elucidate the compounds that are responsible for the observed biological activity of the extract, and this will be reported in due course. 


\section{ACKNOWLEDGEMENTS}

The authors express their profound gratitude to the technologists at the Department of Pharmacognosy, Faculty of Pharmacy, Olabisi Onabanjo University who assisted with the various aspects of this research.

\section{REFERENCES}

1. Shaw, J. E.; Sicree, R. A.; Zimmet, P. Z. Global estimates of the prevalence of diabetes for 2010 and 2030. Diabetes Research and Clinical Practice 2010, 87, 4-14.

2. Rahimi, M. A. Review: anti diabetic medicinal plants used for diabetes mellitus. Bull. Env. Pharmacol. Life Sci. 2015, 4, 163-180.

3. Abo, K. A.; Fred-Jaiyesimi, A. A.; Jaiyesimi, A. E. A. Ethnobotanical studies of medicinal plants used in the management of diabetes mellitus in South Western Nigeria. J. Ethnopharmacol. 2008, 115, 67-71.

4. Tangvarasittichai, S. Oxidative stress, insulin resistance, dyslipidemia and type 2 diabetes mellitus. World J. Diabetes 2015, 6, 456 .

5. Asmat, U.; Abad, K.; Ismail, K. Diabetes mellitus and oxidative stress-a concise review. Saudi Pharm. J. 2016, 24, 547-553.

6. Kayama, Y.; Raaz, U.; Jagger, A.; Adam, M.; Schellinger, I. N.; Sakamoto, M.; Suzuki, H.; Toyama, K.; Spin, J. M.; Tsao, P. S. Diabetic cardiovascular disease induced by oxidative stress. Int. J Mol. Sci. 2015, 16, 25234-25263.

7. Pop-Busui, R.; Ang, L.; Holmes, C.; Gallagher, K.; Feldman, E. L. Inflammation as a therapeutic target for diabetic neuropathies. Curr. Diabetes Rep. 2016, 16, 29.

8. Roy, M. S.; Janal, M. N.; Crosby, J.; Donnelly, R. Markers of endothelial dysfunction and inflammation predict progression of diabetic nephropathy in African Americans with type 1 diabetes. Kidney Int. 2015, 87, 427-433.

9. Gupta, S.; Maratha, A.; Siednienko, J.; Natarajan, A.; Gajanayake, T.; Hoashi, S.; Miggin, S. Analysis of inflammatory cytokine and TLR expression levels in Type 2 diabetes with complications. Scientific reports $\mathbf{2 0 1 7}, 7,7633$.

10. Adaramoye, O.; Amanlou, M.; Habibi-Rezaei, M.; Pasalar, P.; Moosavi-Movahedi, A. Methanolic extract of African mistletoe (Viscum album) improves carbohydrate metabolism and hyperlipidemia in streptozotocin-induced diabetic rats. Asian Pac. J. Trop. Med. 2012, 427-433.

11. Tahrani, A. A.; Piya, M. K.; Kennedy, A.; Barnett, A. H. Glycaemic control in type 2 diabetes: targets and new therapies. Pharmacol. Therapuetics 2010, 125, 328-361.

12. Burkill, H. The flora of west tropical Africa. Kew, Royal Botanic Gardens, United Kingdom 1985, 211.

13. Ogbole, O. O.; Segun, P. A.; Adeniji, A. J. In vitro cytotoxic activity of medicinal plants from Nigeria ethnomedicine on rhabdomyosarcoma cancer cell line and HPLC analysis of active extracts. BMC Comp. Alt. Med. 2017, 17, 494.

14. Ogbole, O. O.; Akinleye, T. E.; Segun, P. A.; Faleye, T. C.; Adeniji, A. J. In vitro antiviral activity of twenty-seven medicinal plant extracts from southwest Nigeria against three serotypes of echoviruses. Virol. J. 2018, 15, 110.

15. Segun, P.; Ogbole, O.; Ismail, F.; Nahar, L.; Evans, A.; Ajaiyeoba, E.; Sarker, S. Bioassayguided isolation and structure elucidation of cytotoxic stilbenes and flavonols from the leaves of Macaranga barteri. Fitoterapia 2019, 134, 151-157. 
16. Ogbole, O.; Segun, P.; Akinleye, T.; Fasinu, P. Antiprotozoal, antiviral and cytotoxic properties of the Nigerian mushroom, Hypoxylon fuscum Pers. Fr.(Xylariaceae). Acta Pharm. Sci. 2018, $56,43-56$.

17. Segun P. A.; Ogbole, O. O.; Akinleye, T. E.; Faleye, T. C.; Adeniji, A. J. In vitro anti-enteroviral activity of stilbenoids isolated from the leaves of Macaranga barteri. Nat. Prod. Res. 2019,

18. Bayne, K. Developing guidelines on the care and use of animals. Annals New York Acad. Sci. 1998, 862:105-110.

19. Prashant, T.; Bimlesh, K.; Mandeep, K.; Gurpreet, K.; Harleen, K. Phytochemical screening and extraction: a review. Int. Pharm. Sci. 2011, 1, 98-106.

20. Okoli, C.; Akah, P.; Nwafor, S.; Anisiobi, A.; Ibegbunam, I.; Erojikwe, O. Anti-inflammatory activity of hexane leaf extract of Aspilia africana CD Adams. J. Ethnopharmacol. 2007, 109, 219-225.

21. Akindele, A.; Adeyemi, O. Antiinflammatory activity of the aqueous leaf extract of Byrsocarpus coccineus. Fitoterapia 2007, 78, 25-28.

22. Zheng, T.; Shu, G.; Yang, Z.; Mo, S.; Zhao, Y.; Mei, Z. Antidiabetic effect of total saponins from Entada phaseoloides (L.) Merr. in type 2 diabetic rats. J. Ethnopharmacol. 2012, 139, 814-821.

23. Hoffman, R. Vascular endothelial dysfunction and nutritional compounds in early type 1 diabetes. Curr. Diabetes Rev. 2014, 10, 201-207.

24. Ngoumfo, R. M.; Ngounou, G. E.; Tchamadeu, C. V.; Qadir, M. I.; Mbazoa, C. D.; Begum. A.; Ngninzeko, F. N.; Lontsi, D.; Choudhary, M. I. Inhibitory effect of macabarterin, a polyoxygenated ellagitannin from Macaranga barteri, on human neutrophil respiratory burst activity. $J$. Nat. Prod. 2008, 71, 1906-1910.

25. Akindele, A.; Oladimeji-Salami, J.; Usuwah, B. Antinociceptive and anti-inflammatory activities of Telfairia occidentalis hydroethanolic leaf extract (Cucurbitaceae). J. Med. Food 2015, 18, 1157-1163.

26. Adeyemi, O.; Okpo, S.; Okpaka, O. The Anti-nociceptive effect of the methanolic extract of Acanthus montanus. J. Ethnopharmocol. 2004, 90, 45-48.

27. Murthy, T.; Kommineni, M.; Mayuren, C. Influenceof losartan on the hypoglycemic activity of glimepiride in normal and diabetic rats. Ther. Adv. Endocrinol. Metab. 2013, 4, 133-138.

28. Xing, R.; He, X.; Liu, S.; Yu, H.; Qin, Y.; Chen, X.; Li, K.; Li, R.; Li, P. Antidiabetic activity of differently regioselective chitosan sulfates in alloxan-induced diabetic rats. Mar Drugs 2015, 13, 3072-3090.

29. Sathya, S.; Kokilavani, R.; Gurusamy, K. Hypoglycemic effect of Gymnema sylvestre (Retz.,) R.Br leaf in normal and alloxan induced diabetic rats. Anc. Sci. Life 2008, 28, 12-14.

30. Fred-Jaiyesimi, A. A.; Bamidele, B. I. Lupeol acetate from Macaranga barteri Mull.-Arg leaf lowers blood glucose level in alloxan induced diabetic rats. Nig. Quart. J. Hosp. Med. 2016, 26, 368-371.

31. Maria, D. P. T.; Gunawan, P.; Jun, K. Novel a-glucosidase inhibitors from Macaranga tanarius leaves. Food Chem. 2010, 123, 384-389. 